Reprod. Nutr. Dévelop., 1984, 24 (5A), 587-595.

\title{
In vivo milk digestion in the calf abomasum. - I. Whole-casein digestion
}

\author{
Mireille YVON, J.-P. PÉLISSIER (1), P. GUILLOTEAU (*), R. TOULLEC (*) \\ Laboratoire de Biochimie et Technologie Laitières, \\ I.N.R.A., 78350 Jouy-en-Josas, France. \\ (*) Station de Recherches sur les jeunes Bovins, I.N.R.A., \\ 65, rue de St-Brieuc, 35042 Rennes Cedex, France.
}

Summary. Peptide products insoluble in $12 \%$ TCA and obtained in the proximal duodenum of calves at different times after ingestion of casein solutions were characterized by polyacrylamide gel electrophoresis, electrofocusing and SDS pore gradient gel electrophoresis.

With a $3 \%$ whole-casein solution in water the disappearance of electrophoretic bands corresponding to $\alpha_{\mathrm{s} 1}$ and $\beta$ caseins was observed after about $1 \mathrm{~h} 30$. After $3 \mathrm{~h}$ and up to $7 \mathrm{~h}$ very acidic peptides appeared. With a $3 \%$ whole-casein solution in simulated milk ultrafiltrate, comparable patterns were obtained. Nevertheless, the acidic peptides appeared sooner, $i$. e. they were already detected in the first sample collected after meal ingestion. With the 2 diets, the importance of gastric proteolysis was demonstrated by the appearance of a great number of peptides of various sizes, charges and $\mathrm{pHi}$. On the other hand, an effect of salts on casein proteolysis was detected.

\section{Introduction.}

In preruminant calves, the abomasum, the functional part of the stomach, secretes chymosin. It has been considered that, although the quantity of pepsin is very low in this stomach compartment of milk-fed calves, it has appreciable activity (Berridge et al., 1943 ; Garnot et al., 1977 ; Guilloteau et al., 1983).

In vitro proteolysis of casein by chymosin or pepsins is relatively well known (Delfour, Alais and Jolles, 1966 ; Fox and Walley, 1971; Creamer, Mills and Richards, 1971 ; Hill, Lahav and Givol, 1974 ; Pélissier, Mercier and RibadeauDumas, 1974 ; Visser and Slangen, 1977 ; Mulvihill and Fox, 1977, 1979a, b ; Addeo, Pélissier and Chianese, 1981 ; Visser, 1981).

(1) All correspondance to : J.-P. Pélissier, I.N.R.A., Laboratoire de Biochimie et Technologie laitières, 78350 Jouy-en-Josas, France. 
A limited number of publications have reported experiments on in vivo proteolysis of milk-proteins in the stomach. These studies deal with gastric emptying in rats (Zebrowska, 1968; Buraczewski et al., 1971; Miranda and Pélissier, 1981, 1983), pigs (Braude et al., 1970a, b) and calves (Toullec, Thivend and Mathieu, 1971 ; Ternouth and Roy, 1973 ; Guilloteau et al., 1975, 1979 ; Pélissier et al., 1983) fed with milk or casein diets. Gastric proteolysis was only partially studied in rats (Miranda and Pélissier, 1981, 1983).

In a previous work (Pélissier et al., 1983), gastric emptying in preruminant calves fed with milk or whole casein solutions has been studied by the determination of $\mathrm{N}$ content of soluble and insoluble fractions in $12 \%$ TCA. In the present work, we characterized peptide products which appeared in the proximal duodenum of calves at different times after the ingestion of casein solutions.

\section{Material and methods.}

Diets and experimental design. - The feeding and collection procedures used for calves have been described previously (Pélissier et al., 1983). The calves received an artificial milk diet containing $25 \%$ of protein from skim-milk. This diet (125 $\mathrm{g}$ dry matter per $\mathrm{kg}$ ) was distributed twice a day. In the morning of the day before sampling, sodium citrate $(11 \mathrm{~g} / \mathrm{kg})$ was added to the " milk " to inhibit coagulation and increase gastric emptying (Frantzen et al., 1973). In the evening, the diet was replaced by water. In these conditions, the abomasum was almost empty before the distribution of the test meal given in the morning.

Each test meal was constituted of $5 \mathrm{~kg}$ of the following diets: (A) $3 \%$ whole-casein solution in water ; (B) $3 \%$ whole-casein solution in simulated milk ultrafiltrate (Jenness and Koops, 1962). Each diet was prepared from the same milk, coming from a single cow homozygous for the 4 caseins $\left(\alpha_{\mathrm{s} 1}, \alpha_{\mathrm{s} 2}, \beta\right.$ and $\left.\chi\right)$. The protein concentration used simulated milk casein concentration.

Animals and sampling. - Two male Frisian calves were fitted with re-entrant cannulas (Ash, 1962) positioned $10 \mathrm{~cm}$ below the pyloric sphincter. The test meals were given from 15 days after the operation and once a week to the same animal. The diets were given twice to one calf and once to the other.

All the digesta leaving the stomach during the first 7 postprandial hours was collected in 10-min fractions for the first hour, in 15-min fractions for the second hour and in 30-min fractions up to the end.

Each digesta was precipitated with trichloracetic acid (TCA), $12 \%$ final concentration, and centrifuged at $2000 \times \mathrm{g}$ for $20 \mathrm{~min}$. The sediment was homogenized in water, extracted 10 times with an equal volume of diethyl-ether to eliminate the TCA and then lyophilized.

Sediments were analyzed by polyacrylamide gel electrophoresis (PAGE), isoelectrofocusing (IEF), SDS-pore-gradient gel electrophoresis (SDS-PGGE) and two-dimensional electrophoresis. No quantitative determination of the products was made because of the presence of unknown peptides from casein proteolysis.

PAGE was performed according to Uriel (1966) with the modifications described by Gripon et al. (1975). IEF, SDS-PGGE and two-dimensional electrophoresis were performed according to Trieu-Cuot and Gripon (1981). 


\section{Results.}

After about $1 \mathrm{~h} 30$ min the bands, observed in PAGE with diet A (casein in water) (fig. 1) and corresponding to the major caseins ( $\alpha_{s 1}$ and $\left.\beta\right)$, disappeared completely. $\chi$-casein disappeared completely from the first sample collected, and a band corresponding to para- $\chi$ casein was visible for about $1 \mathrm{~h} 30 \mathrm{~min}$. Before that time, we detected the transformation of $\alpha_{\mathrm{s} 1}$ and $\beta$-caseins into fast migrating peptides. After $3 \mathrm{~h}$ and up to $7 \mathrm{~h}$, bands appeared at the migration front with diet A. With diet B, (casein and minerals), a comparable pattern was observed (fig. 2). Nevertheless, the fast-moving peptides appeared sooner, i. e. they were already detected in the first sample collected after the meal.

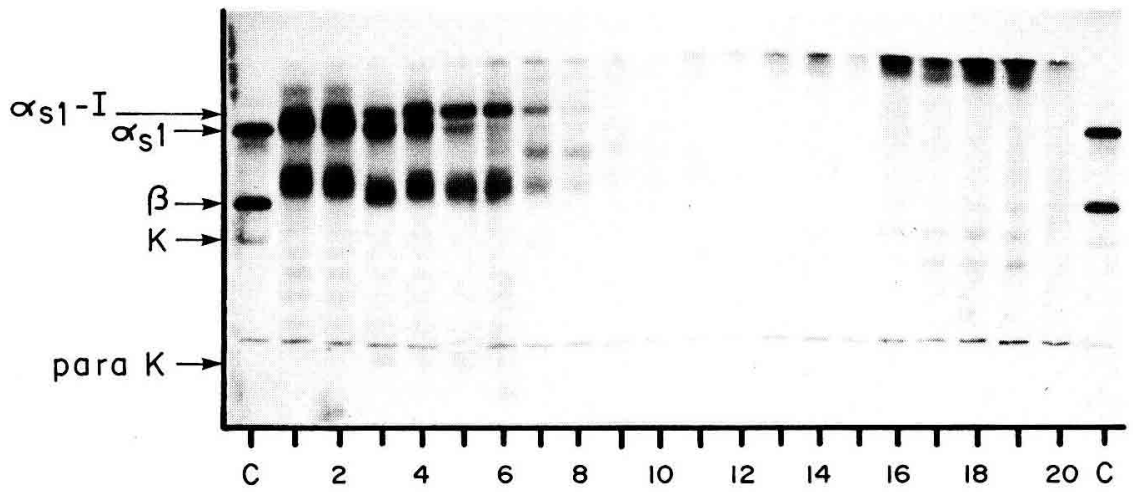

FIG. 1. - Polyacrylamide-agarose ge/ electrophoresis of samples obtained with diet $A$. C : whole casein. Times of sample collection : $1: 0-10 \mathrm{~min} ; 2: 10-20 \mathrm{~min} ; 3: 20-30 \mathrm{~min} ; 4: 30-40 \mathrm{~min}$; $5: 40-50 \mathrm{~min} ; 6: 50-60 \mathrm{~min} ; 7: 60-75 \mathrm{~min} ; 8: 75-90 \mathrm{~min} ; 9: 90-105 \mathrm{~min} ; 10: 105-120 \mathrm{~min}$; $11: 2$ h-2 h $30 ; 12: 2$ h $30-3$ h ; $13: 3$ h-3 h $30 ; 14: 3$ h $30-4$ h ; $15: 4$ h-4 h $30 ; 16: 4$ h 30 5 h ; $17: 5$ h-5 h $30 ; 18: 5$ h $30-6$ h ; $19: 6$ h- 6 h $30 ; 20: 6$ h $30-7$ h.

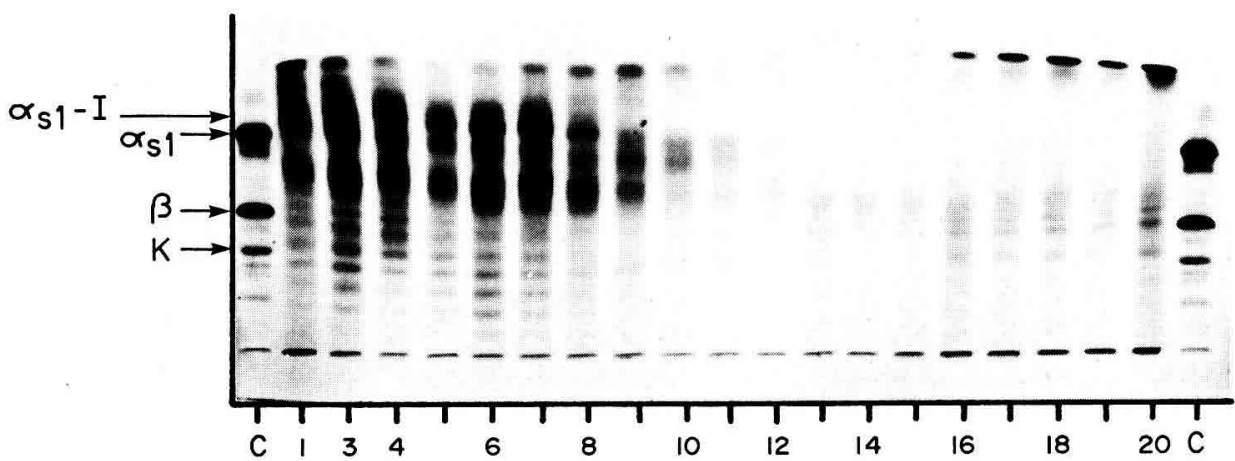

FIG. 2. - Polyacrylamide-agarose gel electrophoresis of samples obtained with diet $B$. See legend of figure 1. 
These results were confirmed by IEF (figs. 3,4 ). The pl values of a large number of peptides were distributed widely. A group of acidic peptides appeared at a rate similar to that observed for the peptides which moved with the migration front in PAGE. During the first hour, we also detected a group of basic peptides which disappeared as the caseins did. In particular, peptides migrating like para- $\chi$ casein and fragment 1-23 of $\alpha_{\mathrm{s} 1}$-casein were evidenced (Trieu-Cuot, 1981).

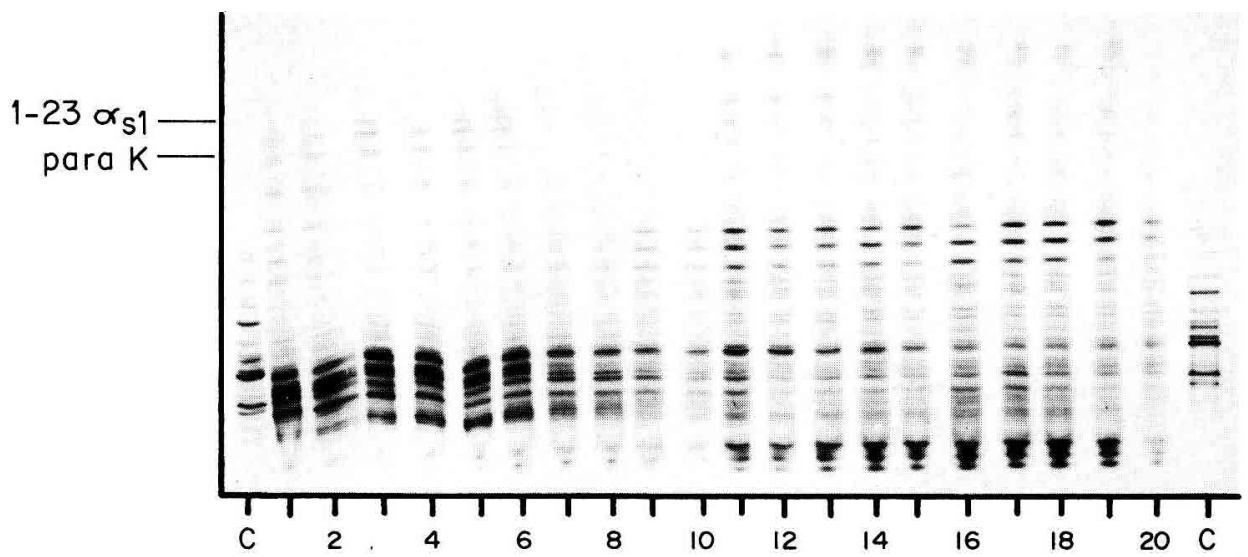

FIG. 3. - Isoelectrofocusing of samples obtained with diet $A$. See legend of figure 1.

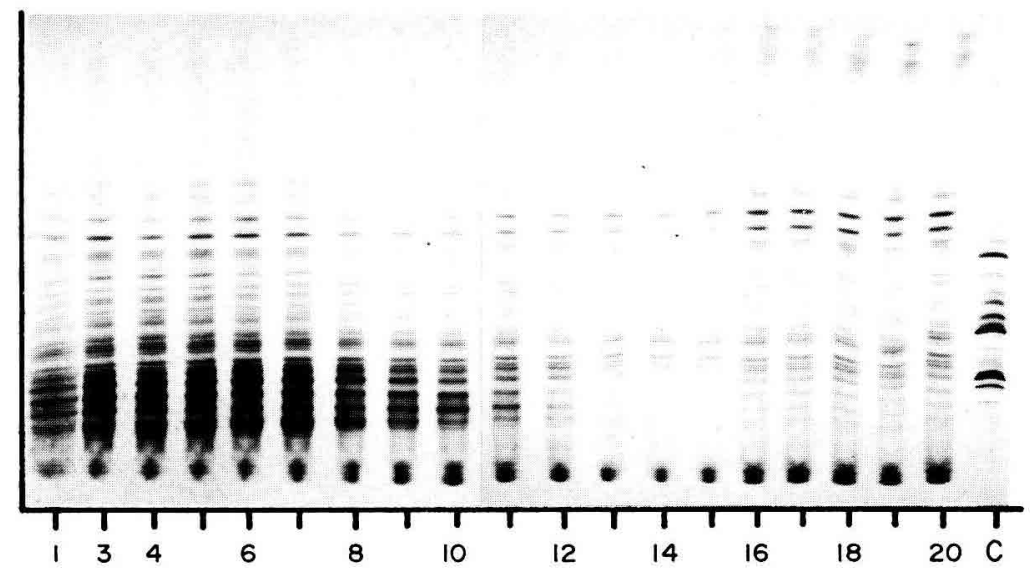

FIG. 4. - Isoe/ectrofocusing of samples obtained with diet $B$. See legend of figure 1.

The molecular weights (MW) of the peptides collected in the duodenum were estimated by SDS-PGGE (figs. 5, 6). For $90 \mathrm{~min}$, most of the products were identified as caseins with little or no proteolysis. Peptides migrating as para kappa and as fragment 1-23 of $\alpha_{\mathrm{s} 1}$-casein could also be detected. On the other 


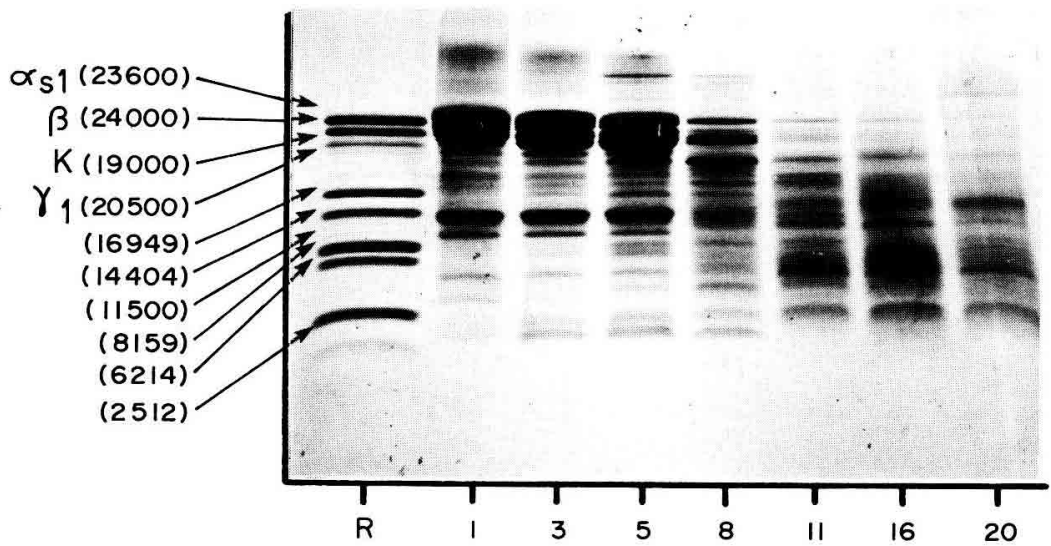

FIG. 5. - SDS-pore-gradient gel electrophoresis of samples obtained with diet A. $\mathrm{R}$ : molecular weight references. See figure 1 for sample collection times.

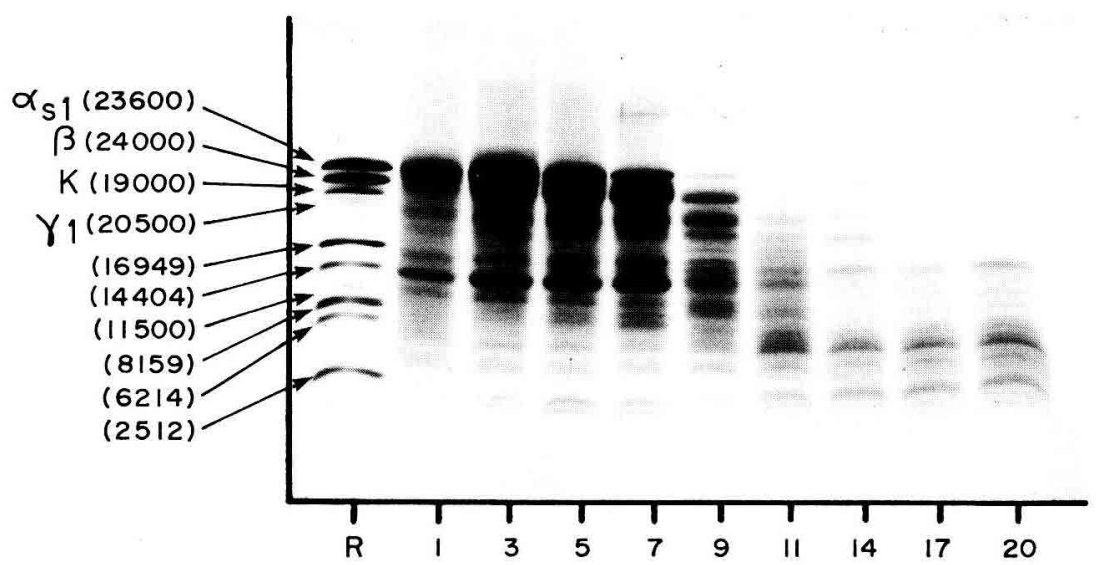

FIG. 6. - SDS-pore-gradient gel electrophoresis of samples obtained with diet $B$. $R$ : molecular weight references. See figure 1 for sample collection times.

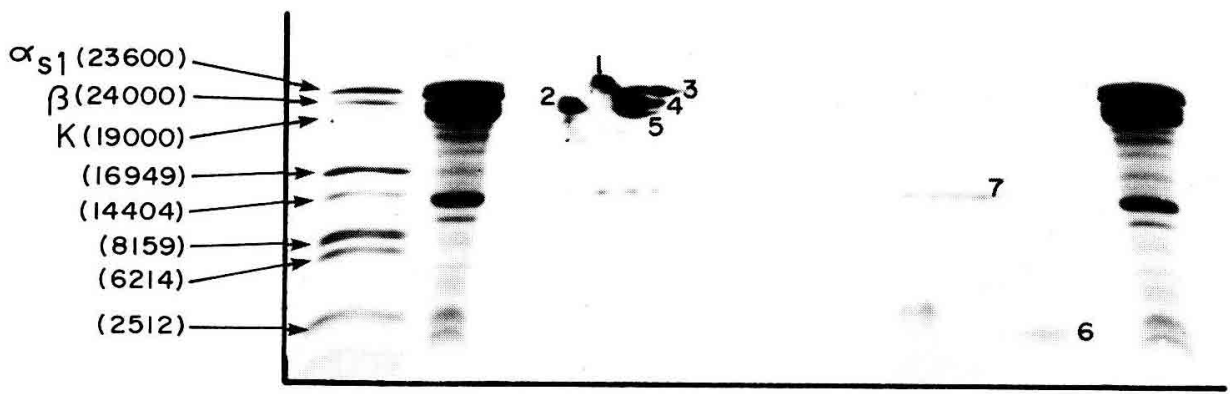

FIG. 7. - Two-dimensional gel electrophoresis of samples obtained with diet $A$. $1: \alpha_{\mathrm{s} 1} ; 2: \alpha_{\mathrm{s} 1}-1 ; 3: \alpha_{\mathrm{s} 2} ; 4: \beta ; 5: \beta-1 ; 6:$ fragment $1-23$ of $\alpha_{\mathrm{s} 1} ; 7:$ para- $\varkappa$. 
hand, after $120 \mathrm{~min}$ the peptides which appeared during digestion had a relatively low MW but were still insoluble in $12 \%$ TCA. These results were confirmed by two-dimensional electrophoresis (figs. 7,8 ) in which these peptides migrated at the same position as $\alpha_{\mathrm{s} 1}-1$ and $\beta$-I did. Digestion products from diet $\mathrm{B}$ appeared to be more proteolysed with this technique. In particular, acidic peptides could be detected with diet $B$ sooner than with diet $A$.

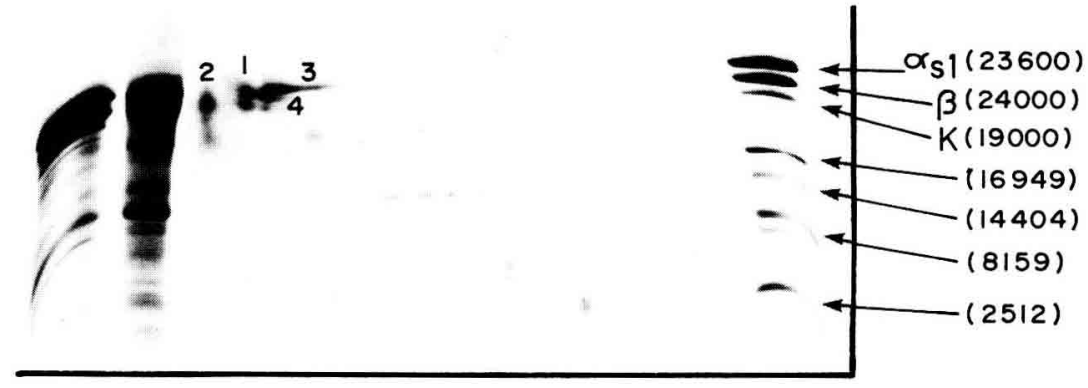

FIG. 8. - Two-dimensional ge/ electrophoresis of samples obtained with diet $B$. See legend of figure 7 .

\section{Discussion.}

With the two diets, the Phe-Met bond of $x$-casein was split very quickly: para- $\varkappa$ casein could be observed in the first collected sample. With casein in water, $\alpha_{\mathrm{s} 1}$ and $\beta$-caseins were present during the first hour after the meal (times 1 to 6). During this first hour, $\alpha_{\mathrm{s} 1}$-casein was partially transformed into a product which migrated farther in PAGE. In IEF, a peptide which migrated as fragment 1 23 of $\alpha_{\mathrm{s} 1}$-casein (Trieu-Cuot, 1981) appeared at a similar rate. These results indicate that during the first hour, $\alpha_{\mathrm{s} 1}$-casein was partly transformed into $\alpha_{\mathrm{s} 1}{ }^{-1}$ (Hill et al., 1974). During the same time, $\beta$-casein was partly transformed into $\beta-\mathrm{I}$ and $\beta$-II (Creamer et al., 1971). Nevertheless, the caseins observed in PAGE at pH 8.6, immediately after the meal, did not migrate exactly as intact caseins did. On the contrary, in PAGE at $\mathrm{pH} 2.9$, their migration was exactly the same as that of intact caseins, and their MW, determined by SDS-PGGE, was similar. These " caseins " seemed to be very close to intact $\alpha_{\mathrm{s} 1}$ and $\beta$-caseins but were slightly modified, probably by adsorption of endogenous products on the caseins. In particular, glycoproteins of the gastric mucosa contain sialic acid (Buddecke, 1972). The presence of such a product would explain the pattern that we obtained.

The presence of almost intact $\alpha_{\mathrm{s} 1}$ and $\beta$-caseins during the first 90 min after ingestion could be explained by the absence of casein coagulation in the stomach. Their disappearance after about $1 \mathrm{~h} 30 \mathrm{~min}$ could be due to two mechanisms, i. e. a decrease of the $\mathrm{pH}$, leading to casein precipitation, and the degradation of the casein into small peptides. Guilloteau et al. (1975) using milk- 
fed calves, obtained a stomach $\mathrm{pH}$ of 5 after about $1 \mathrm{~h} 30 \mathrm{~min}$ of digestion. At such a $\mathrm{pH}$, the caseins would start to precipitate.

The importance of gastric proteolysis is demonstrated by the appearance of small amounts of a great number of peptides of various sizes, charges and pl's. Around $30 \%$ of the ingested $\mathrm{N}$ was emptied during the first 7 postprandial hours (Pélissier et al., 1983). Nevertheless, as the casein diets did not caogulate but were precipitated at acid $\mathrm{pH}$, they displayed particular gastric emptying kinetics. For about $90 \mathrm{~min}$, the major part of the protein products leaving the abomasum corresponded to caseins that were proteolysed slightly or not at all. During this time, only a little more than $10 \%$ of the ingested $\mathrm{N}$ arrived in the duodenum (Pélissier et al., 1983). In these conditions, the largest part of the $\mathrm{N}$ left the abomasum in a proteolysed form.

The peptides which appeared in the duodenum were very different from intact caseins and appeared in the first sample collected. A fast appearance of peptides with mobilities lower than that of $\beta$-casein was observed in PAGE. Only some of these could be $\gamma$-caseins. The other peptides have not been identified. The rapid appearance of these products shows that casein proteolysis by gastric enzymes is different in vivo than in vitro. During in vitro proteolysis by gastric enzymes, $\alpha_{\mathrm{s} 1}$-casein in first degraded into $\alpha_{\mathrm{s} 1}$-I casein (Hill et al., 1974 ) ; $\beta$-casein is successively transformed into $\beta-\mathrm{I}, \beta-\mathrm{II}$ and $\beta-\mathrm{III}$ (Creamer et al., 1971) before undergoing more important proteolysis. At this step, $\alpha_{\mathrm{s} 1}$ and $\beta$-caseins were completely converted into the peptides mentioned above, prior to the significant appearance of other degradation products. On the contrary, we observed in vivo at the same time, little or no proteolysed $\alpha_{\mathrm{s} 1}$ and $\beta$-caseins and peptides originating from a more intensive proteolysis. The kinetics of casein peptide release thus seems to be different in vivo than in vitro.

Peptides which appeared in the duodenum after about $3 \mathrm{~h}$ of digestion moved in PAGE with the migration front. There are two possible explanations : (1) the peptides were small but still insoluble in $12 \%$ TCA or (2) they had a high number of negative charges. Our results using IEF and SDS-PGGE indicate that both types of peptides were present.

With diet B (casein and minerals) the electrophoretic patterns were not exactly the same. The degradation products examined by the different techniques appeared to be the same, but their kinetics of appearance in the duodenum was different. The widest differences were observed for the peptides which moved with the migration front in PAGE. These products appeared sooner $i$. $e$. in the first sample collected, indicating that the action of proteolytic enzymes was more significant with diet B. Indeed, the buffer capacity of diet B was certainly higher thant that of $\operatorname{diet} A$. On the other hand, some of the minerals present in diet $B$ could have affected proteolysis, which would also be modified by ionic strength. According to Fox and Walley (1971), the in vitro proteolysis of $\beta$-casein by bovine rennet is strongly inhibited by $5 \% \mathrm{Nacl}$ and that of $\alpha_{\mathrm{s} 1}$-casein is strengthened. Although diet $\mathrm{B}$ contained only $0.8 \%$ salts, their effect might be intensified in vivo, and it would be easier in these conditions for chymosin to act.

These results were obtained with fasted and cannulated calves. Since the dry matter collected from these animals during the first 7 postprandial hours 
represented only about $30 \%$ of the dry matter of the ingested meals (Pélissier et al., 1983), a large part of the meal digesta was not analysed in our experiment. Nevertheless, our results seem to show that gastric proteolysis in vivo was very intense. On the other hand, salts had a significant effect on casein proteolysis. Hydrolysis was intensified when dietary salts were present. With the techniques used, the peptides obtained with the two diets appeared to be similar but had different appearance kinetics. These results should be confirmed by the isolation and characterization of the peptides collected.

Reçu en décembre 1983. Accepté en mai 1984.

Résumé. Digestion in vivo du lait dans la caillette du veau. l. - Digestion de la caséine entière.

Les produits insolubles en TCA $12 \%$ récoltés dans le duodénum proximal de veaux à différents temps après ingestion de solutions de caséine ont été caractérisés par électrophorèse en gel de polyacrylamide, électrofocalisation, électrophorèse en gel à gradient de porosité en présence de SDS.

Avec une solution à $3 \%$ de caséine dans l'eau, la disparition des bandes électrophorétiques correspondant aux caséines $\alpha_{\mathrm{s} 1}$ et $\beta$ est observée après $1 \mathrm{~h} 30$. Après $3 \mathrm{~h}$ et jusqu'à $7 \mathrm{~h}$ des peptides très acides apparaissent. Avec une solution à $3 \%$ de caséine dans une solution simulant le perméat de lait ultrafiltré, des schémas comparables ont été obtenus. Cependant, les peptides acides apparaissent plus tôt. Ils sont détectés dès le premier échantillon collecté après l'ingestion des repas. Avec les 2 régimes, l'importance de la protéolyse gastrique est mise en évidence par l'apparition d'un grand nombre de peptides de différentes tailles, charges et $\mathrm{pH}$ I. D'un autre côté, l'effet du sel sur la protéolyse des caséines a été mise en évidence.

\section{Références}

ADDEO F., PÉLISSIER J.-P., CHIANESE L., 1980. Specific action of milk clotting enzymes on water buffalo caseins. I. Effect of chymosin on beta-casein. J. Dairy Res., 47, 421-426.

ASH R. W., 1962. Gastro-intestinal reentrant cannulea for studies of digestion in sheep. Anim. Prod., 4, 309-312.

BERRIDGE N. J., DAVIS J. G., KON P. M., SPARTLING F. R., 1943. The production of rennet from living calves. J. Dairy. Res., 13, 145-161.

BRAUDE R., MITCHELL K. G., NEWPORT M. J., PORTER J. W. G., 1970a. Artificial rearing of pigs. I. Effect of frequency and level of feeding on performance and digestion of milk proteins. Brit. J. Nutr., 24, 501-516.

BRAUDE R., NEWPORT M. J., PORTER J. W. G., 1970b. Artificial rearing of pigs. II. The time course of milk protein digestion and proteolytic enzyme secretion in the 28-day old pig. Brit. J. Nutr., 25, 827-842.

BUDDECKE E., 1972. Occurence of glycoproteins in animals and plants. In G/ycoproteins, Vol. 5, part A 535-564. BBA Library Elsevier, London.

BURACZEWSKI S., PORTER J. W. G., ROLLS B. A., ZEBROWSKA T., 1971. The course of digestion of different food proteins in the rat. Brit. J. Nutr., 25, 299-306.

CREAMER L. K., MILLS O. E., RICHARDS E. L., 1971. The action of rennets on the caseins. I. Rennin action on beta-casein solution. J. Dairy Res., 38, 269-280.

DELFOUR A., ALAIS C., JOLLES P., 1966. Structure of cow's kappa caseino glycopeptide : the N terminal octapeptide. Chimia, 20, 148-150.

FOX P. F., WALLEY B. F., 1971. Influence of sodium chloride on the proteolysis of casein by rennet and by pepsin. J. Dairy Res., 38, 165-170. 
FRANTZEN J.-F., TOULLEC R., THIVEND P., MATHIEU C. M., 1973. Influence de la coagulation des protéines sur la vidange stomacale chez le veau préruminant. Ann. Biol. anim. Bioch. Biophys., 13, 718-721.

GARNOT P., TOULLEC R., THAPON J. L., MARTIN P., HOANG M. T., MATHIEU C. M., RIBADEAU-DUMAS B., 1977. Influence of age, dietary protein and weaning on calf abomasal enzymic secretion. J. Dairy Res., 44, 9-23.

GRIPON J. C., DESMAZEAUD M. J., LE BARS D., BERGËR J. L., 1975. Etude du rôle des microorganismes et des enzymes au cours de la maturation des fromages. II. Influence de la présure commerciale. Le Lait, 55, 502-516.

GUILLOTEAU P., PARUELLE J. L., TOULLEC R., MATHIEU C. M., 1975. Utilisation des protéines par le veau préruminant à l'engrais. III. Influence du remplacement des protéines du lait par celles du poisson sur la vidange stomacale. Ann. Zootech., 24, 243-253.

GUILloteAu P., TOULLEC R., SAUVANT D., PARUELLE J. L., 1979. Utilisation des protéines par le veau préruminant à I'engrais. VII. Influence du remplacement des protéines du lait par celles de soja ou de la féverolle sur l'évacuation gastrique. Ann. Zootech., 28, 1-17.

GUILLOTEAU P., CORRING T., TOULLEC R., ROBELIN J., 1983. Effect of age on enzyme activities of abomasum and pancreas of the preruminant calf. In Métabolisme et nutrition azotée. Coll. INRA, S. Publ., 78000 Versailles.

HILL R. D., LAHAV E., GIVOL D., 1974. A rennin-sensitive bond in alpha-s1-B casein. J. Dairy Res., 41, 147-153.

JENNESS R., KOOPS J., 1962. Preparation and properties of a salt solution which simulates milk ultrafiltrate. Neth. Milk Dairy J., 16, 153-164.

MIRANDA G., PÉLISSIER J.-P., 1981. In vivo studies on the digestion of bovine caseins in the rat stomach. J. Dairy Res., 48, 319-326.

MIRANDA G., PÉLISSIER J.-P., 1983. Kinetic studies of in vivo digestion of bovine skim-milk proteins in the rat stomach. J. Dairy Res., 50, 27-36.

MULVIHILL D., FOX P. F., 1977. Proteolysis of alpha-s1 casein by chymosin, influence of $\mathrm{pH}$ and urea. J. Dairy Res., 44, 533-540.

MULVIHILL D., FOX P. F., 1979a. Proteolytic specificity of chymosin on bovine alpha-s1 casein. J. Dairy Res., 46, 641-651.

MULVIHILL D., FOX P. F., 1979b. Proteolytic specificity of chymosin on bovine beta casein. Milchwissenschaft, 34, 680-683.

PÉLISSIER J.-P., MERCIER J.-C., RIBADEAU-DUMAS B., 1974. Etude de la protéolyse des caséines alpha-s1 et beta bovines par la présure. Spécificité d'action. Peptides amers libérés. Ann. Biol. anim. Bioch. Biophys., 14, 343-362.

PÉlISSIER J.-P., GUILLOTEAU P., BRULE G., TOULLEC R., 1983. Digestion des protéines du lait dans la caillette du veau préruminant. Evacuation gastrique après un repas d'épreuve. Reprod. Nutr. Dévelop., 23, 161-173.

TERNOUTH J. H., ROY J. H. B., 1973. The effect of diet and feeding technique on digestive function in the calf. Ann. Rech. Vétér., 4, 19-30.

TOULLEC R., THIVEND P., MATHIEU C. M., 1971. Utilisation des protéines du lactosérum par le veau préruminant à l'engrais. I. Vidange stomacale comparée du lait entier et de deux laits de remplacement ne contenant que des protéines de lactosérum comme source de matières azotées. Ann. Biol. anim. Biochim. Biophys., 11, 435-453.

TRIEU-CUOT P., 1981. Etude des caséines et de leurs produits de dégradation par méthodes électrophorétiques. Th. Univ. Paris, XI.

TRIEU-CUOT P., GRIPON J.-C., 1981. Electrofocusing and two-dimensional electrophoresis of bovine caseins. J. Dairy Res., 48, 303-310.

URIEL J., 1966. Méthode d'électrophorèse dans les gels d'acrylamide-agarose. Bull. Soc. Chim. biol., 48, 969-982.

VISSER S., SLANGEN K. J., 1977. On the specificity of chymosin (rennin) in its action on bovine beta casein. Neth. Milk Dairy J., 31, 16-30.

VISSER S., 1981. Proteolytic enzymes and their action on milk proteins. A review. Neth. Mik Dairy J., 35, 65-88.

ZEBROWSKA T., 1968. The course of digestion of different food proteins in the rat. Fractionation of the nitrogen in intestinal content. Brit. J. Nutr., 25, 299-306. 